\title{
Dangerous Distractions: Imaginary Threats Impede Preparedness for Real Public Health Concerns
}

\author{
Jennifer R. Herricks
}

Published online: 19 September 2014

(C) Springer International Publishing AG 2014

\begin{abstract}
It is easy to think that the most significant public health concerns in the U.S. today are the current outbreak of Ebola in West African and children migrating from Central America. However, as outlined below, these situations may not pose as great a threat as often imagined. Unfortunately, these issues have so dominated the public health agenda in the U.S. that they are actually diverting attention away from genuine public health concerns. For example, the effects of neglected tropical diseases (NTDs) are being felt in Texas and throughout the Gulf Coast states, and yet these conditions are disproportionately ignored and overshadowed.
\end{abstract}

Keywords Ebola $\cdot$ Neglected Tropical Diseases (NTDs) . Texas $\cdot$ West Africa $\cdot$ Central America $\cdot$ Immigration

\section{Improbable Pandemics}

Despite the dangerous spread of Ebola in West Africa, there is little risk that an outbreak will occur in the U.S. [1]. While it is possible that international travel could bring Ebola out of West Africa, healthcare authorities in developed nations would be able to contain its spread adequately. Ebola is not airborne and has a relatively low rate of transmission compared to respiratory infections like the flu. It also cannot be spread unless someone shows visible symptoms of disease.

J. R. Herricks $(\bowtie)$

National School of Tropical Medicine, Baylor College of Medicine,

Houston, TX 77030, USA

e-mail: Herricks@rice.edu

J. R. Herricks

James A. Baker III Institute for Public Policy, Rice University,

Houston, TX 77005, USA
As noted by Dr. Anthony Fauci, director of the National Institute of Allergy and Infectious Diseases, several significant barriers thwart Ebola containment efforts in West Africa [2]. In many of the areas where Ebola has emerged, intense conflict has resulted in a mistrust of authority, making it difficult to educate the population on Ebola. In addition, messages that the sick should be isolated and physical contact with the deceased should be prohibited often conflict with cultural norms. Compounding the situation are poor infrastructure and limited resources.

Not faced with these extreme challenges, the U.S. is fully capable of interrupting local transmission of Ebola should it occur. Even still, there is significant anxiety about Ebola or other foreign infectious agents entering the U.S. One concern is that children migrating to the U.S. from Central America may pose a threat to public health, but this fear is unwarranted [3]. The truth is that many tropical diseases have existed in the U.S. for a long time. These diseases are promoted by conditions of conflict, poverty, warm climate, and the presence of insect vectors. The U.S. is well equipped with the last three factors. As NTDs take their toll on our neighbors, we have neglected to pay attention, and now we are focusing instead on the possibility of improbable pandemics [4].

\section{Diseases of Concern in the U.S.}

Many NTDs are present in the U.S. and cause a variety of health concerns [5]. Some of the most deadly are those spread by insect vectors. Mosquitoes spread dengue fever, West Nile virus (WNV), St. Louis encephalitis (SLEV), and chikungunya fever. Without treatment, these viruses can lead to severe illness with long-term consequences or even death. Chikungunya, for example, causes debilitating joint pain that lasts for years. "Kissing bugs" have been well documented along the Gulf Coast and can spread Chagas disease, which is 
known to cause fatal cardiac complications. Other NTDs can have serious dangerous effects on maternal-fetal health outcomes. A sexually transmitted NTD called trichomoniasis, which rarely causes symptoms, is associated with increased risk of acquiring and transmitting HIV.

These conditions are undoubtedly serious and solving this important public health crisis will require more public awareness and a political will for action. Therefore, it is critical that we balance our concerns and attention. Children who migrate from Central America to the U.S. raise humanitarian and political concerns, but they do not pose a threat to public health. Ebola is a serious problem in West Africa, and we need to help the affected countries and make sure medical teams in the U.S. are ready if Ebola does make its way overseas. However, we should not lose focus of important issues like NTDs that are causing substantial health burdens in our own backyards.

\section{Compliance with Ethics Guidelines}

Conflict of Interest Jennifer R. Herricks declares that she has no conflict of interest.
Human and Animal Rights and Informed Consent This article does not contain any studies with human or animal subjects performed by any of the authors.

\section{Reference}

1. Krisch, J. A. Ebola May Pose Little Threat to U.S., but It Looms Large on Twitter. The New York Times August 10, 2014; http://www. nytimes.com/2014/08/11/world/ebola-may-pose-little-threat-to-usbut-it-looms-large-on-twitter.html. Accessed 11 Aug 2014.

2. Fauci, A. S. Ebola - Underscoring the Global Disparities in Health Care Resources. The New England journal of medicine. August 13, 2014.

3. Hotez, P. Deportations and Deadly Diseases. The Huffington Post July 1, 2014; http://www.huffingtonpost.com/peter-hotez-md-phd/ deportations-and-deadly-d_b 5544701.html. Accessed 11 Aug 2014.

4. Stein, R. The Dread Factor: Why Ebola And 'Contagion' Scare Us So Much. NPR News August 22, 2014; http://www.npr.org/blogs/ goatsandsoda/2014/08/22/342243009/the-dread-factor-why-ebolaand-contagion-scare-us-so-much. Accessed 25 Aug 2014.

5. Hotez PJ, Murray KO, Buekens P. The Gulf Coast: a new American underbelly of tropical diseases and poverty. PLoS Negl Trop Dis. 2014;8(5):e2760. 